\title{
DE LONDRES COM AMOR: A EVOLUÇÃO DO DOMÍNIO INGLÊS NA ECONOMIA PORTUGUESA - 1353-1754
}

Lawrence James Nielsen

Em 1754 o Marquês de Pombal queixava-se de que os ingleses dominavam o comércio de Portugal. Os comerciantes britânicos monopolizavam até o comércio com o Brasil. A mágoa de Pombal era que, em tempos passados, Portugal era mais forte do que a Inglaterra. Por algum tempo, nos séculos XV e XVI, o império português era maior do que o império britânico do século XVIII. Porém, na segunda metade do século XVIII, parecia que os fados, apaixonados com a astúcia econômica e política dos britânicos, tinham decretado que Portugal seria o vassalo econômico da Inglaterra. Pombal, olhando para os tempos passados, culpava o tratado de comércio acertado entre as duas coroas em 1642 como a causa desta dependência. Outros, incluindo economistas ingleses, portugueses e brasileiros modernos, acham que o tratado de comércio de 1703, o famoso Tratado de Methuen, era responsável pelo domínio econômico, e até político em algumas épocas, da Inglaterra nas relações anglo-portuguesas e anglo-brasileiras. Um exame do desenvolvimento destas relações ao longo dos anos, junto com a evolução econômica e política de Portugal e Inglaterra, indica que o referido domínio inglês teve um longo período de gestação, que surgiu principalmente da debilidade de Portugal durante e depois da união das coroas ibéricas no período de 1580 a 1640 , e que de todos os tratados, os de 1642 e 1654 eram de suma importância. Estes últimos serviam de base para futuras negociações.

\section{Evolução da dependência: 1147 a 1640}

As relações entre Portugal e Inglaterra começaram com a ajuda prestada pelos cruzados ingleses encaminhados à Terra Santa, que serviram nas forças do rei Afonso e que expulsaram os mouros do norte de Portugal. Em 1188 e 1189, os ingleses lutaram novamente com os portugueses contra os muçulmanos, e assim auxiliaram o rei Sancho a subjugar os infiéis no sul de Portugal e no Reino de Algarve. Devido às boas relações entre as duas coroas, iniciadas pelos serviços desses cruzados em Portugal, o rei João da Inglaterra, em 1199, escreveu ao rei Sancho, "o prezado irmão e amigo do rei inglês", pedindo a mão de uma princesa portuguesa em casamento. Sancho recusou o pedido. Porém, os portugueses pagaram bem os serviços prestados pelos ingleses. Na Batalha de Bovines, em 1214, tropas portuguesas lutaram ao lado do rei de Inglaterra. ${ }^{1}$

As Cruzadas levaram os ingleses a Portugal, mas foi o comércio que trouxe os portugueses a Inglaterra. Já nos anos do reinado do rei João Sem Terra, comerciantes portugueses residiam em Londres, e até em Dublin, na Irlanda. Nessa época, os ingleses não dominavam o mar e ficavam felizes com a mercadoria estrangeira levada aos portos de 
sua ilha pelos lusitanos. Os portugueses traziam os produtos do mundo mediterrâneo e os vendiam para comprar tecidos e outras manufaturas da Inglaterra. ${ }^{2}$

O comércio português com a Inglaterra aumentou nas últimas décadas do século XIII depois das melhorias da frota marítima introduzidas pelo rei Diniz. No início do século XIV, os lusitanos comerciavam ativamente com a Inglaterra e suas possessões continentais.

A Inglaterra do rei Eduardo III, no entanto, além do comércio, queria algo mais de Portugal. A guerra com a Inglaterra ameaçou eclodir. Eduardo sabia que o futuro e a fortuna de seu reino nesta guerra dependia das alianças alcançadas entre seu país e outros. Queria evitar que os outros se aliassem com a França e aproveitassem nações como Portugal para fortalecer seus exércitos com homens, munições e navios. Para alcançar a aliança com Portugal, Eduardo mandou embaixadas em 1344, 1346 e 1347 com uma proposta de casamento entre seu filho, Eduardo, e a filha do rei Afonso. De novo, não houve um casamento entre as duas coroas. Eduardo III, no entanto, teve mais sorte com as relações comerciais entre os dois reinos. Em 1353, os reis de Portugal e Inglaterra assinaram um tratado de comércio entre as cidades portuguesas de Lisboa e Porto e os portos da Inglaterra e suas possessões. ${ }^{3}$

Depois do tratado de comércio de 1353, as relações entre as coroas eram confusas. A morte de Afonso levou seu filho, Fernando, ao trono lusitano. Este, num primeiro momento, aliou-se com os ingleses. Depois, abandonou esta aliança por uma com a França contra a Inglaterra. Fernando mudou de um lado para o outro até o dia de sua morte, em outubro de 1383.

A morte de Fernando colocou Portugal sob o controle de Castela. Fernando, conhecido como "o Inconstante", pelo fato de não permanecer com nenhum aliado, em uma de suas mudanças tinha casado sua filha com João de Castela. Os grupos dominantes em Portugal, porém, achavam o domínio castelhano contrário a seus interesses. Sob a liderança do meio-irmão de Fernando, João de Avis, os portugueses rebelaram-se contra Castela. Este, dada a superioridade das forças castelhanas, pensou na ajuda estrangeira sua única possibilidade de sucesso - e buscou-a na Inglaterra. Apesar da traição do extinto rei Fernando, e possivelmente por causa dela, o rei Ricardo II deixou os representantes de João de Avis recrutar homens, comprar munições e fazer empréstimos na Inglaterra. Na Páscoa, 2 de abril de 1385, os reforços e abastecimentos chegaram a Lisboa justamente na hora exata para frustrar o sítio naval das forças de João de Castela. A chegada dos reforços ingleses foi o suficiente para dar a vitória a João de Avis e suas forças. Três dias depois da chegada desses reforços, João de Avis aceitou a coroa de Portugal. Em gratidão, também aceitou o tratado de Windsor, assinado no dia 9 de maio de 1386, que selava as negociações de paz e aliança entre as coroas de Inglaterra e Portugal. Pelos termos deste tratado, ambos prometeram ajudar um ao outro contra todos e quaisquer inimigos, sendo ainda garantido salvo-conduto aos súditos de um reino nos territórios do outro. Para fazer esta aliança ainda mais firme, a prima do rei Ricardo II e filha de João de Guant foi dada em casamento ao rei João de Avis. ${ }^{4}$

Do reinado de Ricardo II da Inglaterra e de João I de Portugal até a subida dos Tudores ao trono da Inglaterra, na segunda metade do século XV, as relações entre os dois reinos permaneceram boas e inabaláveis. $\mathrm{O}$ comércio aumentou com os fortes laços desta 
política. E, ainda em face da guerra contínua com a França, Henrique V da Inglaterra mandou uma frota "bem armada", para ajudar o Infante Henrique, o Navegador, filho do rei João, para a captura de Ceuta, em 1415. Da mesma forma, soldados portugueses lutaram com os ingleses na França. Mais, os problemas da sucessão ao trono inglês durante a Guerra das Duas Rosas não abalaram a aliança entre os dois reinos. Os portugueses, com paciência, reconheciam cada novo rei e renovavam o tratado de Windsor a cada mudança de soberano na Inglaterra. ${ }^{5}$

A guerra entre York e Lancaster parece ter favorecido os comerciantes lusitanos e seus negócios. No começo do reinado de Henrique VII, o primeiro Tudor, os comerciantes portugueses estavam bem estabelecidos na Inglaterra e os da Inglaterra em Portugal. Os ingleses vendiam cereais, armaduras, estanho, chumbo, tecidos e outras manufaturas aos portugueses. Por sua vez, os portugueses comerciavam vinho, frutas, mel, cera, óleo de oliva, sal, açúcar, cortiça, especiarias e outros objetos de luxo do Oriente. ${ }^{6}$ Já estavam aparecendo as diferenças e tendências de comércio que iam levar Portugal a depender da Inglaterra. Os portugueses preocupavam-se com produtos primários e de luxo, enquanto tecidos e pequenas manufaturas começavam a ser cada vez mais importantes no comércio exterior dos ingleses.

A amizade secular que existia entre Portugal e Inglaterra, ainda em face do comércio forte entre os reinos, arrefeceu depois da morte de Henrique VII. Dois problemas críticos surgiram para atrapalhar esta amizade. A Inglaterra de Henrique VIII tornou-se protestante e, assim, aos olhos dos portugueses, herege. Portugal aderiu a Espanha e Carlos V em sua cruzada contra os protestantes. Comerciantes e piratas ingleses, do fim do reinado de Henrique VIII até além do reinado de Elizabete I, atacaram as colônias e o comércio marítimo de Portugal. A rixa entre as duas coroas agravou-se em parte porque Portugal excluíra os comerciantes ingleses das suas colônias e possessões de além-mar. As negociações para melhorar as relações comerciais e políticas entre os dois reinos continuaram até a morte do último rei da casa de Avis. O reino de Portugal se uniu com a Espanha em 1580. Com a união das coroas, Portugal herdou de vez todos os inimigos de Espanha. E aqueles ambiciosos da Inglaterra que sonhavam com a conquista dos domínios portugueses podiam se justificar, porque estavam simplesmente lutando contra a Espanha, a Santa Inquisição e a Igreja Católica. ${ }^{7}$

Não há espaço neste trabalho para detalhar a extensão do domínio português de além-mar em 1580 nem para mostrar tudo que Portugal perdeu nas competições predatórias com seus rivais. Basta citar as evidências dadas em resumo por Manoel Faria de Souza, em 1640, e por João Carlos Alves em seu estudo econômico sobre o porto de Lisboa elaborado para o Quinto Centenário do Infante Henrique em 1960.

Manoel Faria e Souza calculou que nas 237 frotas que saíram de Portugal entre 1412 e 1640 , mais ou menos 500.000 homens partiram para nunca mais voltar. Uns 300.000 morreram de peste, em guerras ou naufrágios. Os demais 200.000 ficaram no além-mar para assegurar o domínio português. Esta perda de homens era seriíssima para um país que mal chegava a 1.500 .000 habitantes neste período. Tão desastrosa como esta imigração para a economia portuguesa foram as baixas sofridas que reduziram de maneira significativa a marinha comerciante e bélica de Portugal. Dos 323 navios que zarparam para os domínios portugueses entre 1580 e 1640, 70 foram capturados, sofreram naufrá- 
gios, ou foram destruídos em lutas contra outros europeus. Além da perda de $22 \%$ de sua frota, aqueles que sobraram estavam em mau estado de conservação no ano em que Faria de Souza compilou seu Ásia Portuguesa. ${ }^{8}$

Somente na construção das fortalezas para proteger seus interesses no Oriente, da África até o Japão, os capitães portugueses gastaram 1.368.700 ducados. Durante o "Cativeiro", muitas destas praças caíram nas mãos dos ingleses, dos holandeses e dos povos indígenas que habitavam o território controlado em 1580 pelos lusitanos. Um exemplo do desastre no além-mar, nesse período, foi a perda de Ormuz pelas forças anglo-persas. A coroa portuguesa perdeu sua renda anual de 160.000 escudos que ganhava com os impostos pagos anualmente nesta praça, além do prejuízo sofrido pelos comerciantes. Aqueda de Ormuz significou também para os portugueses a perda do controle dos mares entre Arábia e a India. ${ }^{9}$

Assim, olhando para as baixas econômicas e humanas sofridas pelo reino de Portugal nestes anos de domínio espanhol, João Carlos Alves notou que o "Cativeiro Babilônico" coincidiu com uma crise demográfica e econômica. Houve uma falta séria de mão-de-obra. A produção agrícola e artesanal caiu a tal ponto que os portugueses tinham que depender de importações de comidas e manufaturas estrangeiras para sustentar sua população. ${ }^{10}$

Os portugueses culpavam os espanhóis pelo estado crítico de sua economia. Os espanhóis pareciam prontos a sacrificar os interesses de Portugal para promover os interesses políticos e econômicos dos Habsburgos. A coroa da Espanha nada fez para expulsar os ingleses de Ormuz. Em vez de proteger as frotas com navios, os espanhóis empregavam uma diplomacia que deixou os portugueses caírem vítimas dos holandeses e ingleses. Em desespero, os portugueses seguiram as bandeiras da revolta levantadas pelo Duque de Bragança, o futuro Dom João IV.

Como aconteceu em 1385, Portugal só conseguiu sua independência da Espanha com a ajuda de outros países europeus. A França e os Países Baixos tiveram papel importante para assegurar a independência de Portugal em 1640; mas foi na Inglaterra que Portugal buscou a proteção de suas linhas marítimas de comércio e comunicação. 0 estado de decadência em que se encontrava Portugal à época das negociações do Tratado de 1642 era evidente.

Em virtude de sua posição de fraqueza ao negociar a ajuda inglesa, os portugueses tiveram que reconhecer o direito da East India Company a comerciar no Oriente, dar permissão a dois navios ingleses para operar em portos controlados pelos lusitanos no Oriente e reconhecer direitos ingleses para comerciar na África. Para os ingleses, o tempo em que começaram as negociações para um tratado de paz e amizade em 1641 não poderia ter sido melhor, pois os portugueses estavam também fazendo tratativas com a França e a Holanda. No dia $1 .^{\circ}$ de abril de 1641 , Portugal propôs um tratado com cláusulas que davam aos ingleses o direito de servir no exército e marinha de Portugal com suas próprias tropas e armas, ao mesmo tempo que reconhecia o status quo na Índia, permitindo o livre comércio com os impostos costumeiros. Infelizmente para Portugal, o conhecimento das cláusulas secretas dos tratados entre Portugal, França e Holanda, que favoreciam os últimos mais do que os ingleses, foram divulgadas ao público inglês. Os comerciantes ingleses protestaram no Parlamento e perante a coroa. O governo inglês, 
então, aumentou suas exigências. As negociações continuaram até 1642 . Os termos, finalmente aceitos pelos dois governos, incluíam vinte e uma cláusulas que favoreceram a Inglaterra. Os portugueses ganharam somente o reconhecimento de sua independência da Espanha e uma promessa de amizade inglesa. ${ }^{11}$

No Tratado de Paz e Amizade de 1642, Portugal fez concessões importantes que serviriam mais tarde como base para o Tratado de 1654: tolerância religiosa aos ingleses residentes em Portugal e proteção contra a Inquisição; as contas de ingleses presos pela Inquisição tinham que ser pagas; status de nação mais favorecida foi concedido a Inglaterra e a seus súditos. Assim, os ingleses em Portugal estavam sujeitos aos oficiais do governo inglês e não aos de Portugal e só podiam ser julgados pela coroa da Inglaterra. A porta também foi aberta para os ingleses que queriam comerciar com o Brasil. ${ }^{12}$

Em tudo isso, Portugal teve pouca escolha. Em vez de melhorar, sua dependência econômica somente aumentava. O declínio da produção agrícola era de tal ordem que, entre 1642 e 1648 , mais ou menos $30 \%$ dos navios que atracavam nos portos lusitanos traziam cereais para alimentar o povo. Além de depender cada vez mais dos cereais estrangeiros para fazer o pão de cada dia, Portugal também tinha que importar bacalhau, tecidos, madeiras, ferro, carvão e armamentos. Durante esta crise econômica em que o país dependeu do estrangeiro para sua alimentação, muitas matérias-primas e até manufaturas, como tecidos para se vestir, continuaram a ser importadas até o começo do século XVIII, quando Portugal foi enriquecendo com ouro de Minas Gerais. As linhas de dependência econômica, porém, já estavam bem traçadas e o descobrimento de ouro só agravou esta dependência. ${ }^{13}$ No entanto, a dependência econômica e política de Portugal nas décadas entre 1640 e 1660 o forçou, cada vez mais, a render-se aos ingleses e fortalecer os laços de vassalagem.

\section{Independência sufocada: 1640 a 1740}

Nos dois séculos que se seguiram a sua independência, Portugal dependia da Inglaterra para defendê-lo de três inimigos: Holanda, Espanha e França. Como acontece hoje com os países em desenvolvimento, Portugal tinha que escolher, como aliado, entre as potências da época, aquela que fosse menos ruim. Os reis de Portugal optaram pela Inglaterra, pois esta reconheceu sua independência e, pelo menos em tratados, prometeu respeitar suas possessões. A Inglaterra também era inimiga da França, da Espanha e dos flamengos, e queria controlar seus avanços às custas de Portugal e seu comércio. A Inglaterra deixava os portugueses fazer a conquista e arcar com as despesas de governar terras distantes, enquanto o comércio inglês levava os frutos desses esforços e, com eles, custeava as despesas da evolução de sua vida econômica, política e imperial. De vez em quando, os ingleses enfraqueciam e Portugal se via na contingência de escolher um dos outros três como aliado, mas no fim sempre voltava ao seu velho aliado. Estas, então, são as linhas gerais da dependência de que se queixava Pombal, enfocadas neste trabalho que trata do sufocamento da independência de Portugal pela hegemonia econômica e comercial exercida pelos ingleses, no século que se seguiu a 1640.

Depois de assinado o Tratado de 1642 , a Inglaterra mergulhou no conflito político que a levou à guerra civil. Ao estourar a guerra civil, em agosto de 1642 , o rei João IV deu 
todo o apoio possível a Carlos I contra as forças de Cromwell. Armamento, dinheiro, correspondência entre Carlos e sua rainha e provisões foram levados secretamente para apoiar o monarca Stuart. Quando os puritanos decapitaram Carlos I, Portugal não somente protestou contra o regicídio, mas declarou guerra à república puritana. Infelizmente para João IV e Portugal, isso se tornou insustentável devido à guerra contra Espanha, que se desenvolvia paralelamente. Enfraquecido e sem apoio de outros, Portugal assistiu à captura da frota do Brasil e achou conveniente fazer a paz. ${ }^{14}$

João de Guimarães, plenipotenciário português, chega a Londres para tratar da paz num momento totalmente desfavorável. $\mathrm{O}$ parlamento inglês e aqueles que tinham assassinado Carlos I não queriam a paz. Somente para começar a falar sobre um tratado de paz, os puritanos exigiam que os portugueses indenizassem, no total, todas as custas e perdas sofridas pelos ingleses na guerra. Ao fazer isso, então, a Inglaterra iria começar as negociações e aceitar uma trégua de seis meses. Com uma frota inglesa de 32 navios, com 5.000 mil homens bem armados, estacionados àvista do litoral português, João IV e seus conselheiros acharam melhor aceitar os termos dos ingleses. ${ }^{15}$

Depois de aceitar as condições dos ingleses, a coroa portuguesa mandou o Conde de Penaguião, Rodrigo de Sá e Meneses, para acertar um tratado que fosse o menos prejudicial possível a Portugal. O conde fez o impossível e conseguiu convencer os protestantes a diminuir a soma da reparação para pagar as baixas inglesas. Depois de negociações demoradas, o Tratado de 1654 foi concluído, o que deu aos ingleses tudo que queriam no que diz respeito às relações comerciais com Portugal: domínio quase completo nas relações entre os reinos e suas possessões. Pelo Tratado de 1654, os termos gerais do Tratado de 1642 foram ratificados: navios ingleses podiam operar no Brasil como parte da frota portuguesa e pagar somente os impostos pagos pelos portugueses, comerciantes ingleses podiam negociar livremente no Brasil e o valor de qualquer carga disputada entre os súditos ingleses e os fiscais de Portugal seria estabelecido por uma comissão mista composta de ingleses e portugueses. As importantes cláusulas da extraterritorialidade e da proteção dos comerciantes protestantes ingleses contra a Inquisição foram confirmadas. De qualquer jeito, o Tratado de 1654 favorecia os ingleses e ignorava os direitos dos portugueses. Portugal não ganhou o direito de comerciar livremente com as colônias inglesas nem teve mesma proteção contra os impostos e leis da Inglaterra. É uma ironia da História que a injustiça desse tratado caísse logo sobre a cabeça da família do homem que negociava para Portugal. O irmão do Conde de Penaguião, Pantalião de Sá, participou de uma escaramuça em que alguém morreu. Os puritanos se recusaram a interceder e perdoar o rapaz. O magoado conde assinou o tratado e então fugiu de Londres para não assistir à morte de seu irmão e, ao tentar sair do país, foi preso por causa de dívidas que tinha esquecido de pagar na Inglaterra. Assim, no que tange à cláusula da extraterritorialidade, não havia, por parte da Inglaterra, o respeito que os portugueses tinham aos direitos dos cidadãos ingleses em solo lusitano. ${ }^{16}$

Usando como subterfúgio os termos do tratado que protegia os protestantes da Inquisição, os portugueses protelaram a ratificação do Tratado de 1654 até depois da morte de João IV, em 1656. Os ingleses, cansados com a demora, resolveram forçar os portugueses a ratificá-lo. A presença de uma esquadra inglesa em Lisboa, na época da chegada da frota do Brasil, levou o rei Afonso VI a agir. Cinco dias antes da chegada de 
seus navios, Portugal ratificou o Tratado de 1654. Era a única saída. Portugal não tinha uma marinha de guerra que pudesse fazer frente às forças superiores de Cromwell. ${ }^{17}$

Entre 1657 e 1660, os portugueses estavam na Inglaterra negociando ajuda militar contra os holandeses. Nas vésperas da ratificação do tratado, Carlos II herdou o trono de seu pai. Carlos II encontra os portugueses negociando com os assassinos de Carlos I. Não segue, porém, a mesma política que fizera com outros que tinham negociado e aceitado o governo da República. Os portugueses tinham pestado muita ajuda à sua causa, e, reconhecendo que só o desespero gerado pela guerra com os flamengos tinha forçado seus velhos amigos a tratar com os "criminosos" que assassinaram seu pai, Carlos os perdoou.

De novo, para fortalecer as relações entre os dois reinos, os ingleses propuseram um casamento entre as coroas, desta vez entre Carlos II e a Infanta Catarina de Bragança. Houve obstáculos sérios a este casamento. Catarina, uma católica, não agradava aos protestantes que apoiaram a Restauração. Os católicos da Inglaterra seguiam a política da Espanha e do Papa que recusou reconhecer a independência de Portugal, e, assim, eram contra um casamento com usurpadores em Portugal. Foi oportuno para os proponentes do casamento que a Infanta viesse com um dos maiores dotes pagos na história da Europa.

Os portugueses ofereceram primeiramente " 2.000 .000 de cruzados, cessão de Tanger, guerra perpétua contra os holandeses, e todas as praças capturadas pelos ingleses com a exceção de Ceilão e Mascate". ${ }^{18}$ Os ingleses pediram mais, incluindo a cessão de Pernambuco ou Rio de Janeiro e Bombaim, 4.000.000 de cruzados, e comércio direto entre Brasil e Novafundlândia. Nas negociações que se seguiram, as exigências dos ingleses diminuíram, e o mundo diplomático assistiu ao que parecia impossível: os católicos da Espanha e Inglaterra, junto com o Vaticano, torciam para que Carlos II casasse com uma princesa protestante, enquanto os protestantes da Inglaterra, odiando os católicos, trabalhavam afanosamente para que seu soberano casasse com Catarina, uma católica. ${ }^{19}$

Depois de esvaziar suas negociações, Carlos aceitou Catarina como esposa, possivelmente porque Luís XIV, da França, secretamente mandou dizer que seria um bom negócio para Carlos. A aliança contida no Tratado de 1661 foi assinada e Catarina de Bragança, depois de casar-se com Carlos II, foi proclamada rainha da Inglaterra.

$\mathrm{O}$ tratado que levou Catarina à Inglaterra também assegurou Portugal como um vassalo econômico da Ilha. O tratado ratificou todos os anteriores assinados entre as duas coroas durante a República. Portugal pagou um dote de 2.000 .000 de cruzados. Tanger e Bombaim foram transferidos do domínio de Portugal para o domínio da Inglaterra. Os portugueses permitiram que quatro famílias de comerciantes ingleses residissem em portos da Ásia e do Brasil. Por tudo isso e uma esposa para abusar, Carlos II, numa cláusula secreta do tratado, prometeu defender todos os domínios portugueses dos flamengos e, em outros termos mais públicos, proteger os domínios portugueses no Oriente contra todos e quaisquer inimigos. ${ }^{20}$

Para cumprir sua parte do tratado, os ingleses convenceram a Espanha a reconhecer a independência de Portugal em 1668 e ajudaram os portugueses contra os holandeses em 1661 e 1669. Os portugueses, então, voltaram a atenção para sua situação econômica. Os ingleses preocupavam-se com a manutenção de uma balança favorável no comércio entre as duas nações, com as resoluçōes de seus problemas políticos e com a ameaça do imperialismo da França de Luís XIV. 
Embora, de vez em quando, os problemas políticos o levassem a olhar para a França para assegurar sua independência da Espanha e até se livrar um pouco do domínio econômico da Inglaterra, no fim, Portugal, quando não se mantinha neutro, sempre se alinhou ao lado da Inglaterra nas suas lutas contra a França. E apesar da Pragmática de 1677 que proibiu o uso de alguns tecidos ingleses e a tentativa de fomentar uma indústria de lã para competir com eles, Portugal continuou a depender da Inglaterra nas manufaturas e produtos de primeira necessidade. Assim, a dependência de Portugal aumentava e os ingleses conseguiram manter uma balança favorável de comércio. ${ }^{21}$

Infelizmente, antes dos últimos anos do século XVII, não existem dados suficientes para demonstrar a presença do domínio inglês no comércio com Portugal. Porém, olhando para o número de navios ingleses que aportaram em Portugal para comerciar e a importância crescente da Inglaterra como um mercado para os vinhos portugueses até o fim do século, pode-se ter uma visão sobre o que se passou.

De 1642 até 1678 , verificou-se, no porto de Lisboa, a maior presença dos navios holandeses, ficando os ingleses em segundo plano. Em 1642, dos navios estrangeiros que entraram neste porto, $30,6 \%$ eram holandeses e $24,4 \%$ vinham da Inglaterra e suas possessões. Em 1678, os navios da Holanda alcançaram 43,8\% e os da Inglaterra 37,5\%. Em 1682 , os ingleses superaram os flamengos. Seus navios representaram $43,9 \%$ dos navios estrangeiros e os holandeses $40,3 \%$, perfazendo, entre os dois, um total de $84,2 \%$. Depois de 1682 o número de navios ingleses no porto de Lisboa aumentou, passando o comércio com a Holanda para o segundo plano. ${ }^{22}$

Na década de 1670, quando os ingleses já quase estavam alcançando a média de navios holandeses no porto de Lisboa, os portugueses começaram a desenvolver um mercado para seus vinhos na Inglaterra. Até bem depois do Tratado de Utrecht, o paladar inglês preferira o vinho da França. As guerras entre a Inglaterra e a França, porém, abriram um mercado para o produto português, pois os ingleses não queriam enriquecer seu inimigo mortal com a compra de seus vinhos. Assim, em 1675, a Inglaterra importou 7.500 toneladas de vinho francês e somente 20 toneladas de Portugal. Em 1677, 9.789 toneladas de vinho francês e 176 de Portugal. Com a rivalidade e tensão reinante nos anos de 1682 e 1683 entre a França e a Inglaterra, a importação de vinhos franceses foi reduzidíssima, enquanto 12.000 toneladas de vinho português entraram na Inglaterra em 1682, e 16.000 em 1683. De 1686 a 1690 os vinhos de França recuperaram seu velho lugar nos mercados da Inglaterra e os de Portugal caíram em importância. Com as novas hostilidades que começaram em 1697, houve novos embargos contra vinhos franceses. De 1697 a 1714 , os portugueses mandavam uma média de 6.000 toneladas de vinho por ano à Inglaterra. No mesmo período, os vinhos da França raramente alcançaram 1.000 toneladas num ano. Apesar do aumento da importação do vinho português, a balança de comércio pendia para a Inglaterra. Entre 1696 e 1699, este comércio deu uma renda líquida de 421.520 libras para a Inglaterra. Assim, quando os ingleses propuseram uma aliança na Guerra da Sucessão Espanhola, Portugal queria garantias para proteger sua indústria de vinho. Os ingleses, por sua vez, estavam interessados em acabar com a Pragmática e proteger seu comércio de tecidos. ${ }^{23}$

Em 1701, Pedro II de Portugal assinou um tratado com a França, reconhecendo as pretensões daquela coroa na Espanha em troca de uma promessa de proteção naval contra 
os países que viessem a contestar a dinastia Bourbon na Espanha. De 1701 até junho de 1703, a família Methuen lutou para tirar Portugal da aliança com a França e tê-lo como um aliado contra a mesma França na Guerra da Sucessão. Depois de assistir à vergonhosa derrota da frota hispano-francesa no porto de Vigo, a pouca distância dos seus portos e vendo o não cumprimento, por parte dos franceses, das promessas de enviar navios para proteger seu comércio e litoral, Portugal aceitou os termos dos aliados e entrou em luta contra França e Espanha. Com os detalhes do tratado de aliança assegurados, João Methuen e os portugueses começaram a negociar para proteger seus interesses econômicos mútuos.

É possível que Methuen tivesse começado as negociações com Portugal por iniciativa própria, como, aliás, ele mesmo escreveria mais tarde. Os termos principais do tratado subseqüentemente firmado, porém, tinham sido o assunto de longas negociações entre a Inglaterra e Portugal. Portugal queria proteger seu comércio de vinhos. A Inglaterra pretendia um aumento de seu comércio de tecidos. João Methuen, com interesses econômicos em ambos, o comércio de vinho português e dos tecidos ingleses, e, como antigo membro do House of Commons, tinha conhecimento prévio das conversações sobre assuntos econômicos entre as duas nações. Sendo inglês, porém, ele fez tudo para favorecer o comércio de tecidos. ${ }^{24}$

O Tratado Comercial de 1703, comumente conhecido como o Tratado de Methuen, era surpreendentemente simples. Consistia em três curtos artigos. No primeiro, Portugal prometia adquirir permanentemente manufaturados de lã da Inglaterra nos mesmos termos da Pragmática, se observadas as condições do segundo artigo. No segundo artigo, o soberano inglês prometia que ele e seus sucessores comprariam todos os estoques de vinho de Portugal, com um imposto alfandegário de um terço menos daquele pago pelos vinhos franceses. Na hipótese de a Inglaterra aumentar para mais de dois terços o imposto pago pelos franceses, Portugal teria o direito de proibir a entrada de tecidos de lã ingleses. 0 terceiro artigo deu um prazo de dois meses para o tratado ser ratificado, o que foi feito em dezembro de $1703 .^{25}$

Com o tratado garantido, Methuen, os portugueses e seus aliados se meteram nos negócios mais sérios da Guerra da Sucessão Espanhola. Durante a guerra, Portugal pode ver como a Inglaterra era um aliado perigoso e, nas negociações para pôr fim às hostilidades, teve que agüentar as mudanças políticas na Inglaterra, chegando os ingleses até o ponto de trair seus velhos aliados, ao aceitar uma dinastia Bourbon na Espanha. ${ }^{26}$

No dia 19 de agosto de 1712 , a Inglaterra avisou a seus aliados que tinha acertado um armistício com a França e estava se preparando para retirar suas tropas do continente. Sem as forças da Inglaterra, os aliados se viram forçados a seguir seu exemplo. Depois de uns meses de intrigas e negociações, os beligerantes começaram a tratar sobre o acordo que teria lugar em Utrecht. O plenipotenciário português, o Conde de Tarouca, assistiu à traição inglesa com espanto. Como os demais representantes dos velhos aliados da Inglaterra, queria saber até que ponto os "Tories" iam levar sua traição. Para ele, somente o inferno seria mais confuso e embaraçado do que o Parlamento inglês, que diariamente mudava de rumo. Mas, como a Corte que representava, Tarouca reconhecia que o futuro português, por bem ou por mal, estava ligado à política inglesa. Pelo menos Portugal sairia das negociações com uma vitória moral e não derrotado como teria acontecido se tivesse prosseguido a guerra sem o apoio e a ajuda inglesa. ${ }^{27}$ 
Os termos do Tratado de Utrecht, assinado em abril e maio de 1713, foram ditados na maior parte pelos ingleses e franceses. Os termos favoráveis aos aliados, entre eles Portugal, foram incluídos, é óbvio, porque também serviam aos melhores interesses da Inglaterra, ou não contrariavam de forma alguma a política externa inglesa. Portugal, desta vez, saiu-se mais ou menos bem devido aos interesses da Inglaterra em sua economia. A França abandonou suas pretensões na Bacia Amazônica. Renunciou também seus direitos comerciais no Brasil, adquiridos no tratado comercial de 1667 , e concordou em proibir a seus súbitos da Guiana Francesa de comerciarem com o Brasil. Estas concessões não foram feitas sem ônus para Portugal. $\mathrm{O}$ ministro inglês Bolingbroke teve que ameaçar a França com a renovação de hostilidades e prometer que Portugal desistiria da idéia de construir fortalezas ao longo de suas fronteiras com a Espanha. De jeito nenhum queriam os portugueses abrir mão da construção de tais fortalezas, mas a política inglesa os forçaria a aceitar a realidade. ${ }^{28}$

A dependência política de Portugal foi assinalada no Artigo XXIV do Tratado de Paz e Amizade assinado pela Inglaterra e a França. A Inglaterra assumia a responsabilidade de garantir a paz e os termos do tratado acertado entre a França e Portugal. Com o Tratado de Utrecht, a realidade econômica se juntou com a realidade política. A França abandonou Portugal ao império econômico e político inglês. Luís XIV reconheceu, como o resto da Europa, que o comércio português era da área de influência dos ingleses e que a existência de Portugal como um país independente dependia da marinha da Inglaterra. ${ }^{29}$

A Inglaterra, para cumprir com seus deveres como protetora política de Portugal, começou forçando os espanhóis, através da diplomacia, a aceitar um tratado de paz com Portugal, em 1715. No lado econômico, continuou a gozar dos benefícios de uma balança favorável de comércio com Portugal. Neste comércio, a balança em favor da Inglaterra, entre 1701 a 1710 , era $£ 780.000$. De 1711 a 1720 era de $£ 723.000 ; 1721$ a 1730 , $£ 979.000 ; 1731$ a $1740, £ 1.561 .000$ e de 1741 a $1750, £ 1.476 .000$. Esse estado de coisas continuou até $1760 \mathrm{e}$ as décadas seguintes, quando a balança em favor da Inglaterra começou a diminuir. No entanto, somente no período de 1781 a 1795 a balança de comércio favoreceu Portugal. Nestes cinco anos, os portugueses conseguiram um superavit de $£ 130.000$. Nos cem anos entre 1701 e 1800 a balança em favor da Inglaterra alcançou $£ 8.971 .000 \mathrm{e}$, desde o Tratado de 1654, deve ter alcançado um superavit de $£ 10.000 .000 .^{30}$

O que a Inglaterra vendeu a Portugal para chegar a um superavit tão alto? Vendeu, mais ou menos, os mesmos tipos de mercadorias que Portugal comprara em 1451 e 1640, porém em grande escala e com uma distribuição maior de manufaturas, especialmente tecidos. O valor médio do comércio de tecidos em cada período de cinco anos, entre 1700 e 1760 , nunca baixou de $70 \%$ do valor total do comércio entre as duas nações e seus domínios. Outros artigos vendidos a Portugal, mas em menor escala: pregos e outros artigos de ferro, cobre e latão; pólvora e chumbo (munições); espelhos e outros artigos de vidro; móveis de madeira; artigos de couro; carvão e cereais. Os cereais eram muito importantes no período entre 1731 e 1735 : o trigo chegou a alcançar $12 \%$ do valor total do comércio inglês com Portugal neste período. Nos anos de 1716 e 1720 o comércio de cereais caiu em $5 \%$ do valor total. Em troca, Portugal vendia produtos primários e, principalmente, vinho a Inglaterra. O açúcar, que era importante em seu comércio com Inglaterra, em 1640, tinha sofrido a competição dos holandeses e até das próprias colônias da 
Inglaterra. $\mathrm{O}$ vinho tomou o lugar do açúcar, mas nunca alcançou a importância deste produto do passado. ${ }^{31}$

\section{Conclusões}

Assim, em 1754, o Marquês de Pombal tinha razão para se queixar da situação de dependência econômica de Portugal. Portugal produzia pouca coisa para sua subsistência e os ingleses forneciam dois terços das necessidades de seu querido reino. ${ }^{32}$ Desde o século XVII, lentamente, Portugal foi sendo vítima de sua debilidade diante das potências européias mais fortes e do crescente poder da Inglaterra. O Tratado de 1654 foi de suma importância para a dependência portuguesa da Inglaterra, como também o foi aquele de 1642. O tratado de Methuen era importante, mas não tanto como os outros, pois somente complementou os efeitos do Tratado de 1654 e a evolução econômica e política dos dois reinos entre 1654 e 1703 . O Tratado de Utrecht, por sua vez, simplesmente reconheceu a realidade política e econômica da época; Portugal era o vassalo da Inglaterra que se transformava, na mesma época, em Grã-Bretanha. Pombal tentaria retificar a injustiça do passado e, em parte, sua política diminuiu a dependência secular de Portugal. Infelizmente, para Portugal, um novo período de conflito entre os impérios da França e Inglaterra, depois da Revolução Francesa, ia jogar Portugal e seus domínios mais uma vez sob o jugo da Inglaterra.

\section{Professor Titular, Visitante}

Universidade Federal de Santa Catarina

Bolsista do Latin American Teaching Fellowship Program

\section{NOTAS}

1 Violet Shillington, "The Beginnings of the Anglo-Portuguese Alliance," Transactions of the Royal Historical Society, N.S., 20 (1906), 113-118.

${ }^{2}$ Ibid.

3 Ibid., 118-124.

${ }^{4}$ Ibid., 124-129.

5 A. B. Wallis Chapman, "The Commercial Relations of England and Portugal, 1487-1807," Transactions of the Royal Historical Society, 3rd series, 1 (1907), 157-179.

${ }^{6}$ Ibid.; Alan K. Manchester, British Preeminence in Brazil, Its Rise and Decline: A Study in European Expansion (New York: Octagon Books, 1964), pp. 3-5.

${ }^{7}$ Ibid. 
${ }^{8}$ Manoel de Faria e Sousa, Âsia Portuguesa, tradução de Izabel Ferreira do Amaral Pereira de Matos e Maria Vitória Garcia Santos Ferreira, vol. 4 (Porto: Livraria Civilização, Editora, 1945), p. 518 .

${ }^{9}$ Ibid., pp. 402, 462-463.

10 João Carlos Alves, Quinto Centeneiro do Infante D. Henrique: O porto de Lisboa: Estudo de história económica seguido de um catálogo bibliográfico e iconográfico (Lisboa: Administração-Geral do Porto de Lisboa, 1960), pp. 51-53.

${ }^{11}$ Chapman, op. cit., 116-167; Manchester, op. cit., pp. 6-10; Guernsey Jones, "Beginnings of the Oldest European Alliance: England and Portugal, 1640-1661." Annual Report of the American Historical Association for the Year 1916, vol. I (Washington: 1919), 413.

12 Ibid.

13 João Carlos Alves, op. cit., pp. 51-53.

14 A.B. Wallis Chapman, op. cit., 1596164; Guernsey Jones, op. cit., 409-410.

15 Guernsey Jones, op. cit., 411-412.

${ }^{16}$ Ibid., 412-413.

17 Manchester, op. cit. p. 11.

18 Ibid., p. 415.

19 Ibid.

20 "Marriage Treaty with Portugal, 1661," Andrew Browning, editor, English Historical Documents, vol. VIII, 1660-1714, pp. 852-858.

21 Chapman, op. cit., 168-170.

22 João Carlos Alves, op. cit., p. 43.

${ }^{23}$ Lucio de Azevedo, Épocas de Portugal Económico: Esboço de História (Lisboa: Livraria Clássica Editora de A.M. Teixeira e Cia., 1947), pp. 403-404, 418; Charles Whiteworth, State of the Trade of Great Britain in the Imports and Exports Progressively From the Year 1697 (London: G. Robinson, 1776).

24 A. D. Francis, The Methuens and Portugal, 1691-1708 (Cambridge: University Press, 1966), pp. 126-151, 158-183; Edgar Prestage, "The Anglo-Portuguese Alliance," Transactions of the Royal Historical Society, 4th series, 17 (1934), 92; Great Britain: Parliament, House of Commons, Journal of the House of Commons, 1702-1704, vol. 14 (London: 1803), pp. 290-291.

25 Great Britain: Parliament, House of Commons, op. cit.

${ }^{26}$ Eduardo Brazão, Relações externas de Portugal: Reinado de D. João V (Porto: A Portuguense, 1938), pp. 93-107, 129-133; George Macaulay Trevelyan, England Under Queen Anne: The Peace and the Protestant Succession (New York: Longmans, Green and Co., 1948), pp. 73-88.

${ }^{27}$ George Macaulay Trevelyan, op. cit., pp. 88-91, 222.

28 Eduardo Brazão, op. cit., pp. 238-259; George Macaulay Trevelyan, op. cit., pp. 73-82.

${ }^{29}$ Great Britain: Parliament, House of Commons, Journal of the House of Commons, vol. 17 (London: 1803), p. 330.

${ }^{30}$ Elizabeth Boody Schumpeter, English Overseas Trade Statistics, 1697-1808 (Oxford: Clarendon Press, 1960), pp. 17-18.

${ }^{31}$ H. E. S.Fisher, The Portugal Trade. A Study of Anglo-Portuguese Commerce 1700-1720 (London: Methuen and Co., Ltd., 1971), pp. 15-19.

32 John Smith, Memoirs of the Marquis of Pombal; With Extracts from his Writings and from Dispatches in the State Paper Office Never Before Published, vol. I (London: Longman, Brown, Green, and Longman, 1843), pp. 114-117. 